
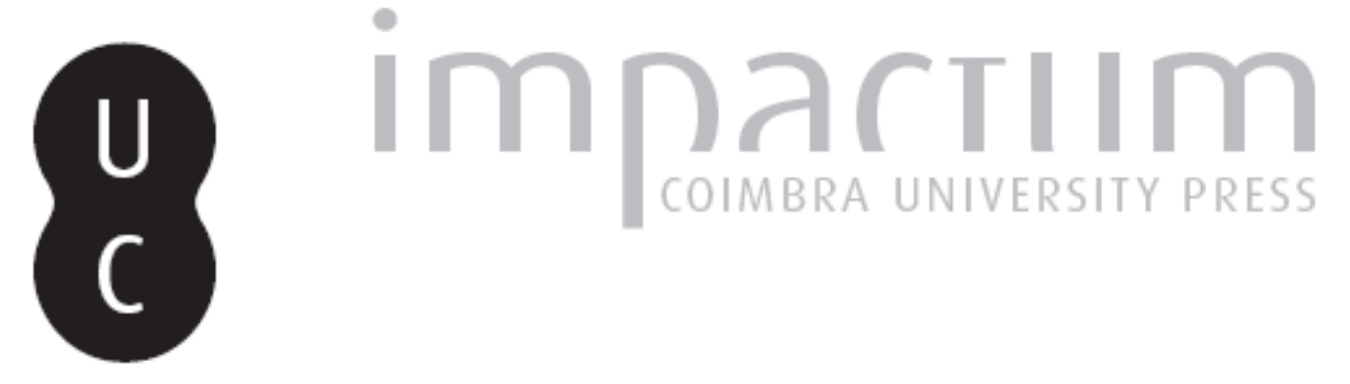

\title{
Paul Krugman's triple doctorate
}

Autor(es): $\quad$ Macedo, Jorge Braga de

Publicado por: Faculdade de Economia da Universidade de Coimbra

URL persistente:

URI:http://hdl.handle.net/10316.2/25236

DOI:

DOI:http://dx.doi.org/10.14195/2183-203X_37_1

Accessed : $\quad$ 26-Apr-2023 14:31:39

A navegação consulta e descarregamento dos títulos inseridos nas Bibliotecas Digitais UC Digitalis, UC Pombalina e UC Impactum, pressupõem a aceitação plena e sem reservas dos Termos e Condições de Uso destas Bibliotecas Digitais, disponíveis em https://digitalis.uc.pt/pt-pt/termos.

Conforme exposto nos referidos Termos e Condições de Uso, o descarregamento de títulos de acesso restrito requer uma licença válida de autorização devendo o utilizador aceder ao(s) documento(s) a partir de um endereço de IP da instituição detentora da supramencionada licença.

Ao utilizador é apenas permitido o descarregamento para uso pessoal, pelo que o emprego do(s) título(s) descarregado(s) para outro fim, designadamente comercial, carece de autorização do respetivo autor ou editor da obra.

Na medida em que todas as obras da UC Digitalis se encontram protegidas pelo Código do Direito de Autor e Direitos Conexos e demais legislação aplicável, toda a cópia, parcial ou total, deste documento, nos casos em que é legalmente admitida, deverá conter ou fazer-se acompanhar por este aviso. 


\section{N $\odot$ T A E C}

$\Delta$

\section{PAUL KRUGMAN'S TRIPLE DOCTORATE}

JORGE BRAGA DE MACEDO

PAUL KRUGMAN JOSÉ SILVA LOPES

ANDRÉ CHAîNEAU

ADÃO CARVALHO

ELSA DE MORAIS SARMENTO /

VANDA DORES /

GUIDA NOGUEIRA

ECONOMISTA MULITANTE

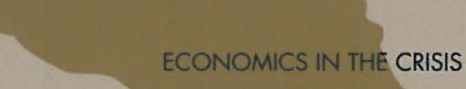

\section{ECONOMICS IN THE CRISIS}

COMMENT

LA MONNAIE ET SẸS SINGULARITÉS

FINANCIAMENTO PÚBLICO Ȧ I\&D EMPRESARIAL EM PORTUGAL

A COMPETIIIVIDADE E A DIVERSIFICAC,ÃO DA FILEIRA FLORESTAL PORTUGUESA

$\rightarrow$

$\Leftrightarrow$

$\odot$

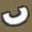

(i)

$\theta$

a)

Q

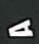
$\theta$ $\infty$ $\Leftrightarrow$ w 


\section{Paul Krugman's Triple Doctorate}

\section{Edited by Jorge Braga de Macedo}

\section{Foreword}

Let me gratefully acknowledge the kind invitation of Coimbra's Notas Económicas to publish NOVA School of Business and Economics Working Paper $n .{ }^{\circ} 566$, including texts prepared for delivery at the first honorary doctorate awarded to Paul Krugman by three Lisbon universities and a note on biology, economics and crises, taken from a meeting at Academia das Ciências de Lisboa.

Before the three Rectors awarded the triple doctorate, Manuel Jacinto Nunes, dean of the Academy's economics and finance section, presented the certificate of foreign corresponding member to Paul Krugman. In fact, Krugman and Olivier Blanchard were elected to the Academy in 2009, and a conference organized by the Academy, the Center for Globalization and Governance at Nova and Instituto de Investigação Científica Tropical was planned for April 2011. This would allow the two new members to interact with academics and businesspeople from Portuguese speaking countries and mark the $30^{\text {th }}$ anniversary of James Tobin becoming a member of the Academy. Due to circumstances beyond our control, the conference was postponed but a progress report on the underlying project titled «Writing to Queens while Crises Proceed" was launched on April 19, 2013 as part of the $130^{\text {th }}$ anniversary celebration of IICT.

Introduced as a «militant economist», Krugman speaks about a crisis «his mind loves but does not let the heart forget the poor and the unemployed». The 2008 Nobel Prize winner - described as a "progressist pessimist of the world economy" - concludes with a severe indictment of the profession. «In normal times, when things are going pretty well, the world can function reasonably well without professional economic advice. It's in times of crisis, when practical experience suddenly proves useless and events are beyond anyone's normal experience, that we need professors with their models to light the path forward. And when the moment came, we failed".

In his comment, the official responsible for Krugman's mission to Portugal in 1976, makes an equally dire prediction: «I would very much like to see in the near future the weakening of the influence not only of freshwater economists but also of their conservative European followers. But I fear that this will not happen until we find ourselves in a more calamitous situation than at present». Silva Lopes hoped in closing «that the ideas of Paul Krugman will soon have more influence in policy makers than at present seems to be the case».

As it turns out, on April 13, 2013 Krugman's blog comes back to his role in the macroeconomic debate about Europe: «In 2010 it (the austerity thing) was based mostly on the logic of the case, not the evidence. Now I can say, 'Look you've done this thing. Look what's happened. Look at Britain. Look at Portugal'.» The difference between the two was already apparent in the lively question and answer period recorded by NOVATV after his Lisbon lecture, to be published in Portuguese. 